V.S. Malyar, O.Ye. Hamola, V.S. Maday, I.I. Vasylchyshyn

\title{
MATHEMATICAL MODELLING OF STARTING MODES OF INDUCTION MOTORS WITH SQUIRREL-CAGE ROTOR
}

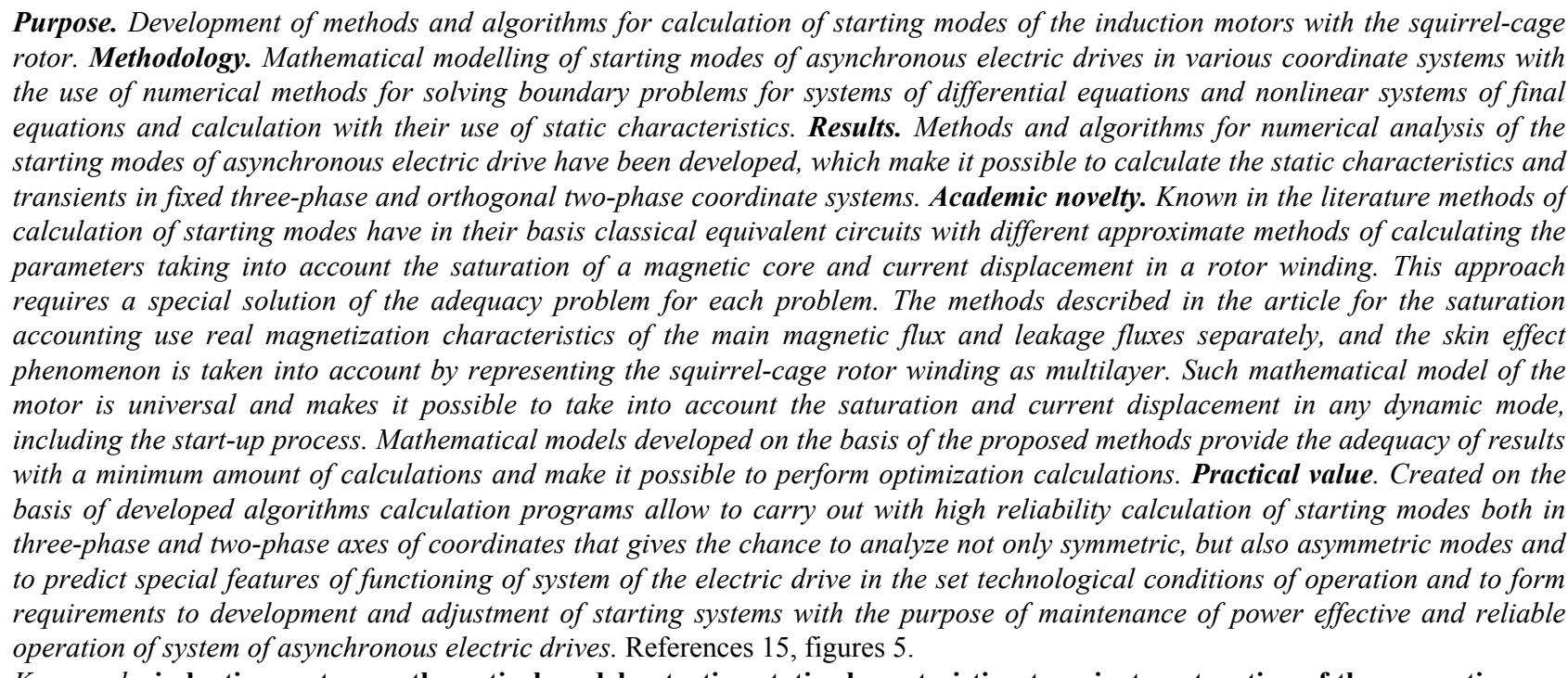
Key words: induction motor, mathematical models, starting static characteristics, transients, saturation of the magnetic core, current displacement, compensation of reactive power.

Розроблено методи і алгоритми числового аналізу пускових режимів асинхронного електроприводу, які дають змогу розраховувати статичні характеристики і перехідні процеси з урахуванням насичення магнітопроводу і явища скін-ефекту в стержня ротора. Математичною основою розроблених алгоритмів є проекційний метод розв'язування нелінійних крайових задач, метод продовження по параметру, метод Ньютона розв'язування нелінійних систем рівнянь, числового інтегрування нелінійних систем диференціальних рівнянь. Розроблені математичні моделі дають змогу здійснювати з високою достовірністю розрахунок пускових режимів у трифазних $і$ двофазних координатних осях, щзо дає змогу аналізувати не тільки симетричні, але й несиметричні режими і прогнозувати особливості функиіонування системи асинхронного електроприводу в заданих технологічних умовах експлуатації. Бібл. 15, рис. 5.

Ключові слова: асинхронний двигун, математичні моделі, пускові статичні характеристики, перехідні процеси, насичення магнітопроводу, витіснення струму, компенсація реактивної потужності.

Разработаны методы и алгоритмы численного анализа пусковых режсиов асинхронного электропривода, которые позволяют рассчитывать статические характеристики и переходные процессы с учетом насыщения магнитопровода и явления скин-эффекта в стержнях ротора. Математической основой разработанных алгоритмов является проекционный метод решения нелинейных краевых задач, метод продолжения по параметру, метод Ньютона решения нелинейных систем уравнений, численного интегрирования нелинейных систем дифференциальных уравнений. Разработанные математические модели позволяют осуществлять расчет пусковых режимов в трехфазных и двухфазных координатных осях, что позволяет анализировать не только симметричные, но и несимметричные режимь и прогнозировать особенности функиионирования системы асинхронного электропривода в заданных технологических условиях эксплуатации. Библ. 15, рис. 5.

Ключевые слова: асинхронный двигатель, математические модели, пусковые статические характеристики, переходные процессы, насыщение магнитопровода, вытеснение тока, компенсация реактивной мощности.

Introduction. Three-phase induction motors (IMs) with a squirrel-cage rotor are the most common in modern electric drives. They are the main consumers of electricity in general and reactive power in particular. One of the problems of asynchronous electric drives is significant starting currents, which affect the quality of electrical energy of the network, which negatively affects other receivers. Despite the short duration of the start-up processes, frequent switching on of the IMs affects the reliability of their operation and reduces the service life. Direct connection of the IM to the network is accompanied not only by significant starting currents, but also by significant pulsations of the electromagnetic torque, and the shock torques affect the bearing assemblies and other elements of the electric drive. Finally, the starting currents of the IM cause electrical losses in the supply line, and if under the conditions of the electric drive operation the frequency of starts is significant, then, accordingly, the share of energy expended on starts is significant. This problem is especially relevant for electric drives with difficult starting conditions, including frequency-regulated ones. 
Analysis of recent research. During start-up, the winding current of the stator of the IM can reach 5-7 times $[1,2]$, which is not always acceptable in specific operating conditions [3]. In addition, for some electric drives (ball mills, various crushers, etc.), which are started under load, it is necessary that the driving torque is several times higher than the critical one $[4,5]$, at which the starting current can exceed the nominal one several times. For long-term operation, this value of current is unacceptable, but it significantly reduces the start-up time [2], and thus reduces the operating time with such current. Prolonged starting of the electric drive with difficult starting conditions can lead to excess of admissible heating of a winding of a stator of the motor, especially in the conditions of frequent starts.

To form the necessary law of change of the electromagnetic torque of the IM in the course of start-up, starting control devices are used [6]. The task of developing an algorithm for the operation of starting equipment under conditions of providing the required driving torque with a minimum value of starting current [2] requires the definition of the laws of change of starting currents and electromagnetic torque.

The starting currents of the IM have a significant reactive component, which can be compensated by static capacitors [6-8]. In particular, to reduce the start-up time of high-power motors, capacitors connected in series to the stator winding can be used, which not only cause an increase in voltage on the motor, but can also cause resonance [9]. In connection with these problems, it is important to choose the starting control equipment, which should provide the necessary mechanical characteristics during the start-up process with the minimum possible power consumption [4, 5]. And since the control equipment and its maintenance requires additional material costs, it is necessary to find a compromise between saving electricity due to the economic flow of start-up processes and the cost of regulation. An overview of methods for improving the energy efficiency of asynchronous electric drives is given in [10].

To optimize the process of starting of the IM, taking into account the operating conditions of the electric drive, it is necessary to analyze it by methods of mathematical modelling. Therefore, the development of methods for calculating start-up processes is an urgent task.

IM is the main element of the electric drive, so the reliability of the calculation results depend on the level of adequacy of its mathematical model, and the speed of calculation codes - on the mathematical method and algorithm for its implementation. High accuracy of calculation of operating modes of the IM cannot be reached with use of their simple mathematical models, and use of a high level of complexity of models demands application of the difficult mathematical apparatus. The level of complexity of the mathematical model of the IM and the methods that must be used to calculate the modes and characteristics of its use are interrelated.

Most methods of calculating start-up modes, including those used in known computing environments, are based on the classic substituting circuits of the IM, which do not always meet the needs of practice. In order to increase the accuracy of calculations, in some works $[4,11]$ the authors divide the start-up process into separate parts. However, reliable information about the course of processes during start-up can be obtained only with the help of highly developed mathematical models of the IM, which adequately take into account all major factors, in particular, changes in inductive resistances due to saturation and in active resistances due to skin effect. In addition, the mathematical model of the electric drive system must take into account the law of change of the moment of resistance on the shaft of the IM during startup [1]. Methods [2, 12, 13], which are based on a combination of field methods with circuit ones, allow to increase the accuracy of determining the electromagnetic torque, but due to their cumbersomeness they are not suitable for real-time control of the electric drive.

The goal of the paper is the development of mathematical models, methods and algorithms for calculating the starting modes of IMs.

Presentation of the main material. The equations of electrical equilibrium of the circuits of the IM, written for physical circuits, have the form

$$
\frac{d \boldsymbol{\Psi}}{d t}+R \boldsymbol{i}=\boldsymbol{u}
$$

where $\boldsymbol{\psi}=\left(\psi_{1}, \ldots, \psi_{k}\right)^{*}, \boldsymbol{i}=\left(i_{1}, \ldots, i_{k}\right)^{*}$ are the vectors of flux linkages and currents of $k$ circuits (superscript $(*)$ means transposition); $R$ is the diagonal matrix of active resistances; $\boldsymbol{u}$ is the vector of applied voltages.

The mathematical model of the IM requires the calculation of flux linkages $\psi$ and electromagnetic parameters $L=\partial \boldsymbol{\psi} / \partial \boldsymbol{i}$ according to the selected coordinate system. The flux linkage of each winding is a complex nonlinear function $\psi=\psi(i, \gamma)$ of the currents of all its circuits and the position of the rotor, which is determined by the angular coordinate $\gamma$ of the rotor rotation. Therefore, differential equations (DEs), written for instantaneous values of physical coordinates, have periodic coefficients that complicate their solution. However, most practically important problems can be solved using transformed coordinate systems, which are based on the theory of image vectors $[6,14]$, the purpose of transition to which is to subtract the rotor rotation angle from the equations of electrical equilibrium of the circuits of the IM.

The question of choosing a coordinate system is of fundamental importance for the development of mathematical models of specific dynamic modes of electric drives. Both the volume of calculations and the accuracy of the calculation results depend on the chosen coordinate system. The developed methods the following are used:

a) a system of fixed three-phase axes that coincide with the physical axes of the stator phases;

b) a system of orthogonal axes $x, y, 0$, which rotate at any speed. 
Magnetic cores of modern IMs have a high level of saturation, which causes nonlinearity of dependencies of flux linkages of circuits on currents, so mathematical models based on the assumption of their linearity do not provide the possibility of calculating dynamic modes with the required accuracy for modern engineering practice. Linearization of electromagnetic connections in the IM does not solve the problem, because in a real machine the saturation varies widely and is determined by the instantaneous values of the currents of all circuits. In the developed mathematical models for calculation of a matrix $L$ of differential inductances of circuits of the IM, the basic characteristic of magnetization $\psi_{\mu}=\psi_{\mu}\left(i_{\mu}\right)$ is used as dependence of working flux linkage on magnetization current $i_{\mu}$ and dependencies of flux linkages of scattering of circuits of stator $\psi_{\sigma s}=\psi_{\sigma s}\left(i_{s}\right)$ and rotor $\psi_{\sigma r}=\psi_{\sigma r}\left(i_{r}\right)$ windings on the respective stator $(s)$ and rotor $(r)$ currents, which are calculated based on the geometric dimensions of the magnetic core and winding data.

In addition to saturation, the processes in the IM in dynamic modes are significantly affected by the phenomenon of current displacement in the rods of the squirrel-cage rotor, taking into account which in the starting modes is essential. Its consideration by artificial methods on the basis of the predicted distribution of penetration into the depth of the slot of the electromagnetic wave is probabilistic. Methods of taking into account the skin effect based on the calculation of the magnetic field in the slot of the machine $[12,13]$ are unacceptable due to their cumbersomeness. In the developed mathematical models, the rotor rods and shortcircuiting rings are divided into $n$ layers in height, which allows to solve the problem based on the theory of circuits [9]. As a result, we obtain $n$ short-circuited windings on the rotor, between which there is a mutual inductive connection due to both the main magnetic flux and the scattering fluxes.

A mathematical model in fixed three-phase coordinates. Processes in the IM are described by a system of finite and differential equations compiled according to the Kirchhoff first and the second laws. To calculate the transients, it is expedient to replace the finite equations drawn up according to the Kirchhoff first law with differential ones. As a result, in a fixed three-phase coordinate system, electromagnetic processes are described by the DE system, which consists of three equations for the stator circuits

$$
\begin{aligned}
& \frac{d \psi_{A}}{d t}-\frac{d \psi_{B}}{d t}=u_{A B}-r_{A} i_{A}+r_{B} i_{B} ; \\
& \frac{d \psi_{B}}{d t}-\frac{d \psi_{C}}{d t}=u_{B C}-r_{B} i_{B}+r_{C} i_{C} ; \\
& \frac{d i_{A}}{d t}+\frac{d i_{B}}{d t}+\frac{d i_{C}}{d t}=0,
\end{aligned}
$$

and $3 n$ equations for $n$ equivalent rotor windings

$$
\begin{aligned}
& \frac{d \psi_{a j}}{d t}-\frac{d \psi_{b j}}{d t}=-r_{a j} i_{a j}+r_{b j} i_{b j}-\alpha\left(\psi_{b j}-2 \psi_{c j}+\psi_{a j}\right) \\
& \frac{d \psi_{b j}}{d t}-\frac{d \psi_{c j}}{d t}=-r_{b j} i_{b j}+r_{c j} i_{c j}-\alpha\left(\psi_{c j}-2 \psi_{a j}+\psi_{b j}\right) \\
& \frac{d i_{a j}}{d t}+\frac{d i_{b j}}{d t}+\frac{d i_{c j}}{d t}=0 ; \quad(j=1, \ldots, n),
\end{aligned}
$$

where $\alpha=\omega_{0}(1-s) / \sqrt{3} ; s$ is the sliding; $\omega_{0}$ is the motor supply voltage frequency; $\psi_{k}, i_{k}, r_{k},\left(k=A, B, C, a_{j}, b_{j}, c_{j}\right)$ are the phase flux linkages, currents and active resistances, respectively, $j=1, \ldots, n ; u_{A B}, u_{B C}$ are the instantaneous values of line voltages.

The problem of starting the electric drive system requires a study of the process of breaking the IM taking into account the mechanical characteristics of the working mechanism $[1,5]$ in the form of the dependence of the instantaneous value of the load torque on the shaft $M_{c}=M_{c}(t)$ on time or angle of rotation of the rotor which may exceed its maximum passport value in operating mode $[4,5]$. An important problem is the study of motor acceleration time to nominal speed [2], especially for electric drives with difficult starting conditions. Often speed is the main requirement for the operation of technological equipment. To form the necessary characteristics of the electric drive system, specially programmed starting systems are used $[1,6]$, which can be done using appropriate mathematical models.

To calculate the electromechanical process of starting the IM it is necessary to supplement the DE system (2) with the equation of mechanical equilibrium

$$
\frac{d \omega}{d t}=\frac{p_{0}}{J}\left(M_{e}-M_{c}\right)
$$

where $\omega$ is the angular speed of rotation of the rotor; $p_{0}$ is the number of pole pairs of the IM; $J$ is the moment of inertia of the electric drive system reduced to the motor shaft.

The electromagnetic torque of the IM in the phase coordinates is determined by the formula

$$
M_{e}=p_{0}\left(\psi_{A}\left(i_{B}-i_{C}\right)+\psi_{B}\left(i_{C}-i_{A}\right)+\psi_{C}\left(i_{A}-i_{B}\right)\right) / \sqrt{3},
$$

where $\psi_{A}, \psi_{B}, \psi_{C}, i_{A}, i_{B}, i_{C}$ are the projections of the image coupling vectors of the flux linkage $\psi_{\mu}$ and the magnetization current $\boldsymbol{i}_{\mu}$ on the corresponding phase axes.

The DE system (2) together with equation (3) makes it possible to calculate the transient of starting the IM. To do this, it is necessary to integrate it numerically under zero initial conditions, calculating at each step of integration the matrix of differential inductivities and the vector of flux linkages [14].

Example of calculation of the start-up process of the IM 4A160M6Y3 $\left(P_{N}=15 \mathrm{~kW}, U_{N}=380 / 220 \mathrm{~V}\right.$, $s_{N}=0.026 ; k_{M \max }=2.0 ; k_{M 1}=1.2 ; n_{N}=1000 \mathrm{rpm} ; k_{I 1}=6$; $\cos \varphi_{N}=0.875$ ) with a nominal load for different values of the moment of inertia of the electric drive system is shown in Fig. 1 

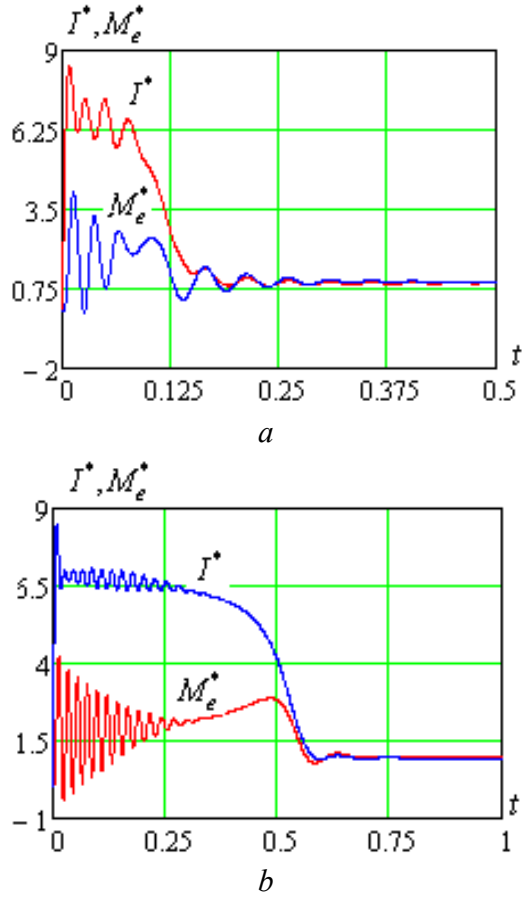

Fig. 1. Time dependencies of relative values of stator current $\left(I^{*}\right)$ and electromagnetic torque $\left(M_{e}^{*}\right)$ during start-up of the IM with nominal moment of loading and various moments of inertia:

$$
J-(a) \text { and } 5 J-(b)
$$

In order to present the projection method for calculating the steady state, we write system (2) in the form of a vector DE

$$
\frac{d \boldsymbol{\psi}(\boldsymbol{i}, t)}{d t}=z(\boldsymbol{\psi}(\boldsymbol{i}, t), \boldsymbol{u}(t))
$$

in which the periodic perturbation is the vector of applied voltages $u(t)=u(t+T)$.

In the steady state (at a constant sliding value $s$ ), the solution of the DE system (4) is the $T$-periodic time dependencies of the components of the vector $\boldsymbol{i}(t)=\boldsymbol{i}(t+T)$. The problem of their definition can be most effectively solved in the timeless domain by solving the boundary value problem using developed on the basis of the general theory of nonlinear oscillations the projection method, the theoretical basis of which is the approximation of state coordinates by splines. To do this, we approximate each coordinate of the vector $\psi$ on the mesh of $N$ nodes of the period by a third-order spline in accordance with what was stated in [15]. As a result, we obtain a continuous function, which is on every $j$-th time section $h=t_{j}-t_{j-1}(j=1, \ldots, N)$ is described by the equation of the form

$$
\psi(t)=a_{j}+b_{j}\left(t_{j}-t\right)+c_{j}\left(t_{j}-t\right)^{2}+d_{j}\left(t_{j}-t\right)^{3},
$$

spline coefficients, the ratio between which is determined by its properties. In particular,

$$
\psi\left(t_{j}\right)=\psi_{j}=a_{j}, \quad d \psi /\left.d t\right|_{t=t_{j}}=-b_{j} .
$$

As a result, we obtain a system of discrete equations

$$
H \boldsymbol{\Psi}-\boldsymbol{Z}=0,
$$

in which $H$ is the transition matrix from the continuous change of coordinates to their nodal values [15], the elements of which are determined only by the mesh of nodes in the period; $\boldsymbol{\Psi}=\left(\boldsymbol{\psi}_{1}, \ldots, \boldsymbol{\psi}_{N}\right)^{*} ; \boldsymbol{Z}=\left(\boldsymbol{z}_{1}, \ldots, \boldsymbol{z}_{N}\right)^{*}$; $\boldsymbol{U}=\left(\boldsymbol{u}_{1}, \ldots, \boldsymbol{u}_{N}\right)^{*}$ are the column vectors, the components of which are the nodal values of the corresponding vectors of the system (4).

The system (5) of algebraic equations is a discrete analogue of the DE system (4). Its solution is a vector of nodal values of coordinates, the dependence of which on sliding $s$ can be obtained by the differential method. To do this, we differentiate system (5) by $s$

$$
W \frac{d \boldsymbol{\Psi}}{d s}=\frac{d \boldsymbol{Z}}{d s},
$$

where $W$ is the Jacobi matrix.

As a result of integrating the nonlinear DE system (6) by one of the numerical methods by $s$ we obtain a multidimensional characteristic in the form of a set of periodic time dependencies of nodal coordinates for each sliding, using which we obtain the dependencies of flux linkages, electromagnetic torque and so on. An example of static characteristics calculations for the 4A160M6Y3 motor is shown in Fig. 2.
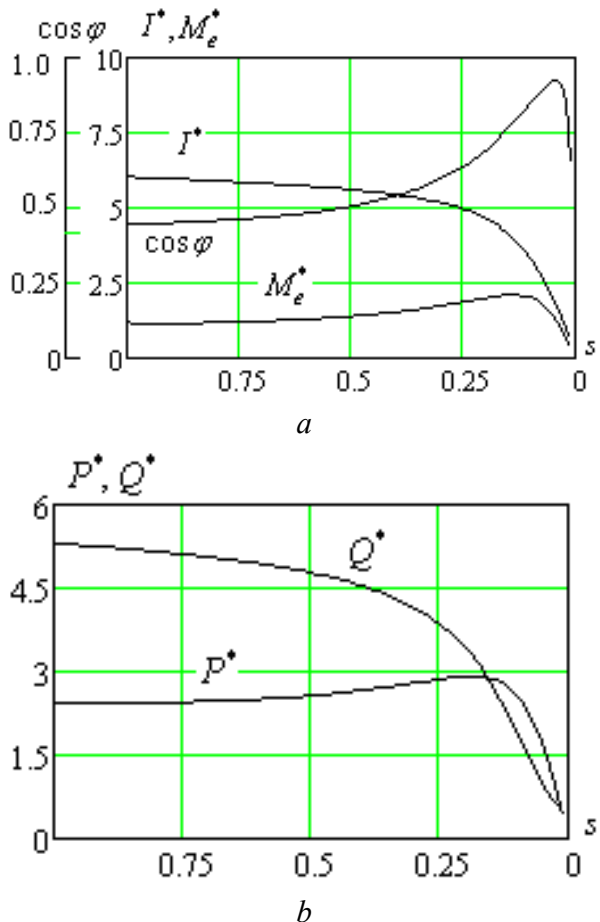

Fig. 2. Starting characteristics of the IM for current $\left(I^{*}\right)$, electromagnetic torque $\left(M_{e}^{*}\right)$ and $\cos \varphi(a)$, as well as active $\left(P^{*}\right)$ and reactive $\left(Q^{*}\right)$ powers $(b)$ in relative units

Features of mathematical modelling of starting modes of the electric drive with individual compensation of reactive power. The so-called cosine capacitors can be connected in series or in parallel. For mathematical modelling of starting modes of the electric drive with longitudinal compensation it is necessary to replace the first two equations (2a) of the system in the initial DE system DR with those in which the presence of series-connected capacitors is taken into account:

$$
\begin{aligned}
& \frac{d \psi_{A}}{d t}-\frac{d \psi_{B}}{d t}=u_{A B}-r_{A} i_{A}+r_{B} i_{B}-u_{k A}+u_{k B} ; \\
& \frac{d \psi_{B}}{d t}-\frac{d \psi_{C}}{d t}=u_{B C}-r_{B} i_{B}+r_{C} i_{C}-u_{k B}+u_{k C},
\end{aligned}
$$


where $u_{k A}, u_{k B}, u_{k C}$ are the voltages on capacitors, and supplement it with equations

$$
\frac{d u_{k A}}{d t}=\frac{i_{A}}{C} ; \quad \frac{d u_{k B}}{d t}=\frac{i_{B}}{C} ; \quad \frac{d u_{k C}}{d t}=\frac{i_{C}}{C} .
$$

In this case, the voltage drop across the phase capacitors affects the supply voltage of the motor, and therefore the electromagnetic torque, current and power can far exceed the nominal values. An example of the dependencies of the effective values of current, power and electromagnetic torque on the capacitance of seriesconnected capacitors, made on the basis of the calculation of currents and flux linkages of the circuits of the motor 4A160M6U3 at $s=1$ is shown in Fig. 3.

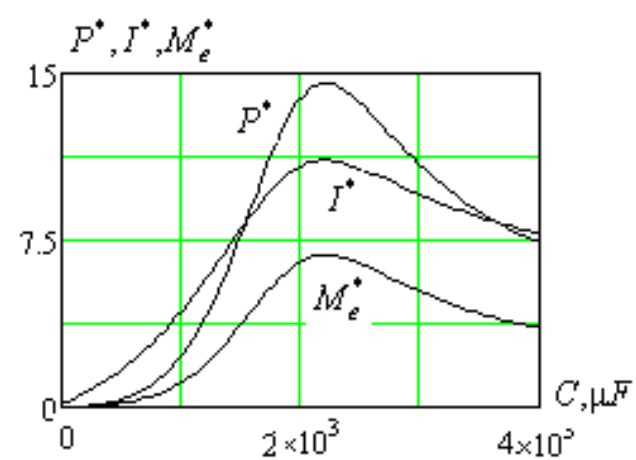

Fig. 3. Dependencies of relative values of current $\left(I^{*}\right)$, active power $\left(P^{*}\right)$ and electromagnetic torque $\left(M_{e}^{*}\right)$ of the IM on the capacitance of series-connected capacitors

If the capacitors are connected in parallel to the IM, the mathematical model described by the system of equations (2) does not require changes, because the currents in them can be found separately, as the voltage on them is known. The currents in the supply line $i_{A}^{\prime}, i_{B}^{\prime}$, $i_{C}{ }_{C}$ are defined as the sum of the currents of the motor $i_{A}$, $i_{B}, i_{C}$ and parallel connected capacitors $i_{A k}, i_{B k}, i_{C k}$. An example of the results of the calculation of the periodic dependences of the instantaneous values of the currents of phase $A$ is shown in Fig. 4, and the dependencies of their effective values (in p.u.) and $\cos \varphi$ on the value of the capacitance of the capacitors - in Fig. 5.

The value of the capacitance selected by the static characteristic must be checked in the dynamic mode by calculating the transient because the capacitors connected in series can lead to the appearance of resonant phenomena $[6,9]$.

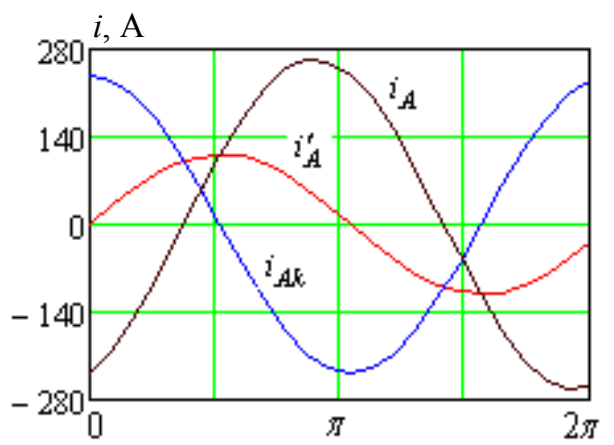

Fig. 4. Curves of currents of phase $A$ :

$i_{A}^{\prime}-$ supply line; $i_{A k}-$ capacitor; $i_{A}-$ motor

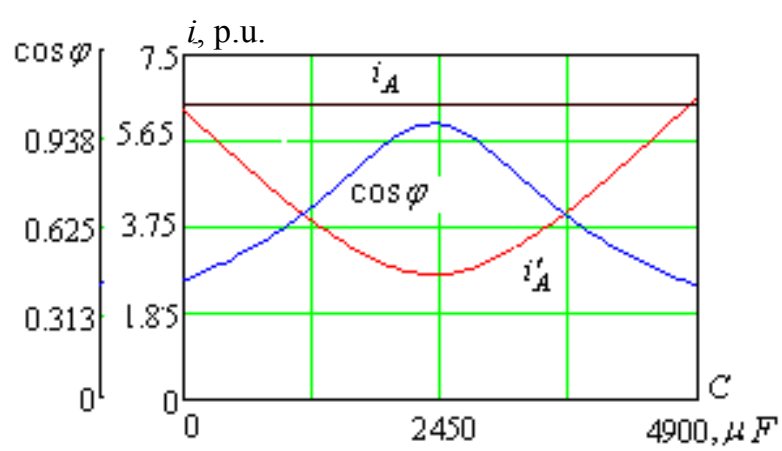

Fig. 5. Dependencies on the capacitance of the effective values of currents of phase $A$ :

$i^{\prime}{ }_{A}$ - supply line; $i_{A}$ - motor and of $\cos \varphi$ of the electric drive systems with capacitors connected in parallel

A mathematical model in orthogonal coordinates. In symmetrical modes of operation of the IM in the absence of higher harmonics in the supply voltages of the stator, the starting modes can be considered in orthogonal coordinates. The mathematical model of the electric drive system in the coordinate basis converted to orthogonal axes is much simpler than the model in three-phase axes, but its scope is narrowed.

Consider a mathematical model for studying the starting characteristics of the IM using a system of coordinate axes $x, y$. To do this, the three-phase stator winding and formed by the rotor rods $n$ equivalent threephase windings are reduced to the $x, y$ axes. As a result, we will have two windings on the stator and $2 n$ windings on the rotor. The DE system of electrical equilibrium of circuits has the form

$$
\begin{gathered}
\frac{d \psi_{s x}}{d t}=\omega_{0} \psi_{s y}-r_{s} i_{s x}+u_{s x} \\
\frac{d \psi_{s y}}{d t}=-\omega_{0} \psi_{s x}-r_{s} i_{s y}+u_{s y} \\
\frac{d \psi_{1 x}}{d t}=s \omega_{0} \psi_{1 y}-r_{1} i_{1 x} ; \\
\frac{d \psi_{1 y}}{d t}=-s \omega_{0} \psi_{1 x}-r_{1} i_{1 y} ; \\
\quad \vdots \\
\frac{d \psi_{n x}}{d t}=s \omega_{0} \psi_{n y}-r_{n} i_{n x} \\
\frac{d \psi_{n y}}{d t}=-s \omega_{0} \psi_{n x}-r_{n} i_{n y}
\end{gathered}
$$

where $\psi_{s x}, \psi_{s y}, \psi_{1 x}, \psi_{1 y}, \ldots, \psi_{n x}, \psi_{n y}$ are the flux linkages and $i_{s x}, i_{s y}, i_{1 x}, i_{1 y}, \ldots, i_{n x}, i_{n y}$ are the currents of transformed circuits; $r_{s}, r_{1}, \ldots, r_{n}$ are their active resistances.

The DE system (7) together with the equation of rotor motion

$$
\frac{d s}{d t}=-\frac{p_{0}}{J \omega_{0}}\left(\frac{3}{2} p_{0}\left(\psi_{s x} i_{s y}-\psi_{s y} i_{s x}\right)-M_{c}\right)
$$

allows to investigate the process of starting of the IM with or without load $\left(M_{c}=0\right)$ by solving the Cauchy problem in the time domain.

Under the condition of constant sliding, the DE system (7) is transformed into a system of ordinary nonlinear equations 


$$
\begin{gathered}
-\omega_{0} \psi_{s y}+r_{s} i_{s x}=U_{m} ; \\
\omega_{0} \psi_{s x}+r_{s} i_{s y}=0 ; \\
-s \omega_{0} \psi_{1 y}+r_{1} i_{1 x}=0 ; \\
s \omega_{0} \psi_{1 x}+r_{1} i_{1 y}=0 ; \\
\vdots \\
-s \omega_{0} \psi_{n y}+r_{n} i_{n x}=0 ; \\
s \omega_{0} \psi_{n x}+r_{n} i_{n y}=0 .
\end{gathered}
$$

The multidimensional static characteristic as the dependence of the mode coordinates on the sliding can be calculated by solving the system of equations (8) for the sequence of sliding values $s$. One of the ways to determine the solution of system (8) at a given value of sliding $s$ is the method of differentiation by parameter. To do this, write it in vector form

$$
\boldsymbol{y}(\psi, i, s)=\boldsymbol{u},
$$

multiply the vector $\boldsymbol{u}$ by the scalar parameter $\varepsilon(0 \leq \varepsilon \leq 1)$ and differentiate the obtained system by the parameter $\varepsilon$. As a result, we get the DE

$$
A \frac{d \boldsymbol{i}}{d \varepsilon}=\boldsymbol{u} .
$$

Integrating the vector $\mathrm{DE}$ (10) by $\varepsilon$ (which can be done by the Euler method in a few steps), we obtain the value of the vector of currents $i$, which is refined by the Newton iterative method. The initial conditions (the value of the vector $i$ ) are zero, because for $\varepsilon=0$ the vector of applied voltages is zero. The increment $\Delta \boldsymbol{i}^{(k)}$ of the current vector $\boldsymbol{i}$ at the $k$-th iteration step is determined by the formula

$$
A \Delta \boldsymbol{i}^{(k)}=-\boldsymbol{Z}\left(\boldsymbol{i}^{(k)}\right),
$$

where $\boldsymbol{Z}\left(\boldsymbol{i}^{(k)}\right)$ is the residual vector of system (9) at given values of sliding $s$ and the voltage vector $\boldsymbol{u}^{(k)}$.

In the case of series-connected capacitors, the first two equations of system (8) have the form

$$
\begin{gathered}
\omega_{0} \psi_{s y}-r_{s} i_{s x}+x_{c} i_{s y}=u_{s x} ; \\
-\omega_{0} \psi_{s x}-r_{s} i_{s y}-x_{c} i_{s x}=u_{s y},
\end{gathered}
$$

where $x_{c}=1 /\left(\omega_{0}(1-s)\right) ; u_{s x}=U_{m} ; u_{s y}=0$.

Given a number of sliding values $s$ of the rotor of the IM, we can get a multidimensional static characteristic in the form of the dependence of the coordinates on the sliding.

Conclusions and prospects for the development of the direction. One of the most important modes of asynchronous electric drive is the start-up process, so in the technical literature the problem of its analysis is given considerable attention. Various computer technologies are developed for the design of controlled asynchronous electric drives and their control systems, the basis of which are applied computer codes necessary for the analysis of electromechanical processes in electric drives. Not only quantitative but also qualitative indicators of the electric drive system, which must provide the necessary mechanical characteristics determined by the technological process and meet modern requirements for energy efficiency, depend on their adequacy. To solve these problems, the paper develops mathematical models that adequately reflect the electromagnetic processes in the IM and do not require significant computing resources. In particular, the design of the electric drive system requires the choice of its elements, including the starting control equipment, which can be done by calculating the static characteristics. With their help it is possible to determine the limit values of currents, torque, power, etc. in order to establish the functioning of the starting control equipment.

The developed calculation methods are based on the mathematical model of the IM, which takes into account both the change of natural and mutual differential inductive resistances of the motor due to saturation of the magnetic core and active resistances of squirrel-cage rotor winding due to current displacement in the rods. The mathematical model for the calculation of static characteristics in three-phase braked axes is based on solving the boundary value problem for DE of the first order with periodic boundary conditions and allows to perform optimization calculations with minimal computational costs. A feature of the model is the ability to investigate the processes at asymmetry of supply voltages, as well as at the presence of capacitors with longitudinal compensation of reactive power.

For symmetrical modes of operation the method of calculation of modes and characteristics in orthogonal coordinate axes $x, y$ is developed which allows to carry out calculation with the minimum volume of calculations and accordingly expenses of computation time, and therefore to use the developed algorithm for control of the electric drive system in dynamic modes in real-time process. However, its use is limited to symmetrical modes of operation of the electric drive.

Peculiarities of using the developed mathematical models and algorithms for research of influence of capacitors on parameters of the electric drive at longitudinal and cross compensation of reactive power are presented.

Conflict of interest. The authors declare no conflict of interest.

\section{REFERENCES}

1. Chernyiy, A.P., Gladyir, A.I., Osadchuk, Yu.G., Kurbanov, I.R., Voshun, A.N. Starting systems of unregulated electric drives. Kremenchug: PF Shcherbatykh A.V., 2006, 280 p. (Rus). 2. Abhishek Garg, Arun Singh Tomar. Starting time calculation for induction motor. International Journal of Engineering Research and Applications, May 2015, vol. 5, iss. 5, pp. 56-60. Available at: http://www.ijera.com/papers/Vol5 issue $5 / \mathrm{Part} \% 20$ $\% 203 / \mathrm{J} 505035660 . \mathrm{pdf}$ (accessed 12.10.2020).

3. Hashimov A.M., Rahmanov R.N. Starting-Up Impact of Powerful Asynchronous Motors Used at Gas-Compressor Units on GRID Mode. ENERGETIKA. Proceedings of CIS higher education institutions and power engineering associations. 2012, no. 1, pp. 17-22. (Rus).

4. Belyaev V.P., Skakun V.V. Dynamics of processes of startup of the asynchronous electric drive. Proceedings of BSTU, 2015, no. 9 (182), pp. 34-40. Available at: https://elib.belstu.by/bitstream/123456789/17345/1/dinamika- 
processov-puska-asinxronnogo-ehlektroprivoda-dynamics-ofprocesses-of-start-up-of-the-asynchronous-electric-drive-v.-p.belyaev-v.-v.-skakun-v.-p.-belyaev-v.-v.-skakun.pdf (accessed 12.10.2020). (Rus).

5. Khrebtova O. Forming the induction motor torque when starting. Technical Electrodynamics, 2020, no. 5, pp. 40-44. doi: https://doi.org/10.15407/techned2020.05.040.

6. Aflyatunov I.F. Asinkhronnyi elektroprivod s kondensatornym pusko-reguliruiushchim ustroistvom: dis. kand. tekhn. nauk [Asynchronous electric drive with capacitor start up regulator device. Cand. tech. sci. diss.]. Ulyanovsk, UlGTU Publ., 2016. 150 p. Available at: https://www.dissercat.com/content/asinkhronnyielektroprivod-s-kondensatornym-pusko-kompensiruyushchimustroistvom (accessed 12.10.2020). (Rus).

7. Vishnevskiy L.V., Muha N.I., Pavlenko S.S. Pusk asinkhronnykh elektrodvigatelei $s$ kompensatsiei reaktivnoi moshchnosti: monografiia [Start of asynchronous motors with reactive power compensation]. Odessa, NU OMA Publ., 2016. 160 p. (Rus).

8. Gorbachevskiy N.I., Aflyatunov I.F. Investigation of starting an induction motor with capacitors in series in the stator circuit. Bulletin of the Kazan Technological University, 2013, vol. 16, no. 12, pp. 112-114. Available at: https://www.elibrary.ru/download/elibrary $19141286 \quad 433555$ 38.pdf (accessed 12.10.2020). (Rus).

9. Malyar V., Hamola O., Maday V., Vasylchyshyn I. Mathematical modeling of processes in asynchronous motors with capacitors connected in series. 2015 16th International Conference on Computational Problems of Electrical Engineering (CPEE), Lviv, Ukraine, 2015, pp. 107-109. doi: https://doi.org/10.1109/cpee.2015.7333350.

10. Diachenko G.G., Aziukovskyi O.O. Review of methods for energy-efficiency improvement in induction machines. Naukovyi Visnyk Natsionalnoho Hirnychoho Universytetu, 2020, no. 1, pp. 80-88. doi: https://doi.org/10.33271/nvngu/2020$\underline{1 / 080}$.
11. Khrisanov V.I. Analysis of starting transients of squirrelcage induction motor. The start-off stage. Russian Electrical Engineering, 2010, vol. 81, no. 3, pp. 109-114. doi: https://doi.org/10.3103/S1068371210030016.

12. Kocman S., Orsag P., Pecinka P. Simulation of Start-Up Behaviour of Induction Motor with Direct Online Connection. Advances in Electrical and Electronic Engineering, 2018, vol. 15, no. 5, pp. 754-762. doi: https://doi.org/10.15598/aeee.v15i5.2342. 13. Zamchalkin A.S., Tyukov V.A. Numerical modeling of process of start-up of the induction motor. Proceedings of TUSUR University, 2012, no. 1 (25), part 1, pp. 171-177. Available at: https://journal.tusur.ru/storage/45503/171.pdf?1466640193 (accessed 12.10.2020). (Rus).

14. Kulagin D.O. The mathematical model of asynchronous traction motor taking into account the saturation of magnetic circuits. Naukovyi Visnyk Natsionalnoho Hirnychoho Universytetu, 2014, no. 6, pp. 103-110. Available at: https://nvngu.in.ua/index.php/en/component/jdownloads/finish/5 0-06/1538-2014-6-kulagin/0 (accessed 12.10.2020). (Ukr).

15. Malyar V.S. Main provisions of the spline method for calculating the periodic operation modes of electric circuits. Electronics and Communications, 1998, no. 5, pp. 11-14. (Rus).

Received 12.11.2020

Accepted 01.02.2021

Published 05.04.2021

V.S. Malyar ${ }^{1}$, Doctor of Technical Science, Professor,

O.Ye. Hamola ${ }^{1}, P h D$, Associate Professor,

V.S. Maday ${ }^{1}$, PhD, Associate Professor,

I.I. Vasylchyshyn ${ }^{1}, \mathrm{PhD}$, Associate Professor,

${ }^{1}$ Lviv Polytechnic National University, 12, S. Bandera Str., Lviv, 79013, Ukraine, e-mail: vasyl.s.maliar@lpnu.ua, orest.y.hamola@lpnu.ua, volodymyr.s.madai@lpnu.ua

How to cite this article:

Malyar V.S., Hamola O.Ye., Maday V.S., Vasylchyshyn I.I. Mathematical modelling of starting modes of induction motors with squirrel-cage rotor. Electrical Engineering \& Electromechanics, 2021, no. 2, pp. 9-15. doi: 10.20998/2074-272X.2021.2.02. 